Bот. Gaz. 146(4):489-494. 1985.

(c) 1985 by The University of Chicago. All rights reserved.

0006-8071/85/4604-0006\$02.00

\title{
MORPHOLOGICAL AND PHYSIOLOGICAL RESPONSES TO IRRADIANCE IN THE CAM EPIPHYTE TILLANDSIA USNEOIDES L. (BROMELIACEAE) ${ }^{1}$
}

\author{
CRAIG E. MARTIN,* KENNETH W. McLEOD, † CAROL A. EADES, ${ }^{*}$ AND ANGELA F. PITZER* \\ *Department of Botany, University of Kansas, Lawrence, Kansas 66045; and †Savannah River Ecology Laboratory, \\ P.O. Drawer E, Aiken, South Carolina 29801
}

\begin{abstract}
Spanish moss (Tillandsia usneoides L.) was collected in situ in South Carolina from sunny and shady locations and grown in a greenhouse under high and low irradiance. Morphological characteristics, including leaf size, internode length, trichome size and density, and stomatal size and density, were similar among plants at the different irradiance levels. Chlorophyll (Chl) a/b ratios did not change with irradiance, but total Chl concentrations were higher in plants exposed to lower irradiances. In spite of these changes in pigment composition, similar levels of nocturnal acidification were found in field, but not greenhouse, plants at all irradiance levels. Thus, Spanish moss can respond physiologically, but not morphologically, to changes in environmental irradiance levels. This ability should prove beneficial to an epiphyte growing in microsites of widely varying irradiance.
\end{abstract}

\section{Introduction}

Morphological differences between plants growing in full sunlight or dense shade include: (1) larger, thinner leaves on shade plants, (2) less dense stomata on shade leaves, (3) less reflective leaves on shade plants, and (4) less deeply lobed leaves on shade plants (TALBERT and HOLCH 1957; BOARDMAN 1977; DENGLER 1980; WILD and WOLF 1980; BJÖRKMAN 1981). Often accompanying these structural features are physiological differences between sun and shade leaves: (1) greater concentration of total $\mathrm{Chl}$ in shade leaves; (2) lower $\mathrm{Chl} \mathrm{a/}$ $\mathrm{b}$ ratios in shade plants, reportedly reflecting a larger light-harvesting $\mathrm{Chl} \mathrm{a/b-protein} \mathrm{complex} \mathrm{contain-}$ ing all of the Chl b, but not all of the $\mathrm{Chl} \mathrm{a}$, in the chloroplast; (3) greater proportion of maximum photosynthetic rates in shade leaves at LI; (4) greater rates of photosynthesis in sun leaves at $\mathrm{HI}$; and (5) larger molar ratios of $\mathrm{Chl}$ to electron transfer components in chloroplasts of shade plants (BOARDMAN 1977; BJÖRKMAN 1981). All the above differences between sun and shade leaves act directly or indirectly to enhance rates of photosynthesis in the habitat of each plant.

Because of the temporal separation of photosynthetic events in CAM plants, it is difficult to study photosynthetic responses to changing irradiance. Increasing daytime irradiance results in greater nocturnal acid accumulations, at least in two species of Kalanchoe (ZABKA and EDELMAN 1962;

\footnotetext{
${ }^{1}$ Abbreviations: CAM, Crassulacean acid metabolism; Chl, chlorophyll; DW, dry weight; FAA, formalin-acetic acid-alcohol; GHI, greenhouse high irradiance; GLI, greenhouse low irradiance; HI, high irradiance; LI, low irradiance; MI, medium irradiance; PAR, photosynthetically active radiation.

Manuscript received November 1984; revised manuscript received May 1985.

Address for correspondence and reprints: C. E. MARTIN, Department of Botany, University of Kansas, Lawrence, Kansas 66045 .
}

KAPLAN et al. 1976a, 1976b), Ananas comosus (Nose et al. 1977; SALE and NEAlEs 1980), and in several desert succulents (WoODHOUSE et al. 1980; NOBEL and HARTSOCK 1978, 1983; NOBEL 1982a, $1982 b$, 1983). Light saturation of nocturnal acid accumulation and of $\mathrm{CO}_{2}$ uptake in desert succulents occurs at integrated daytime irradiance levels of $20-24 \mathrm{~mol} \mathrm{~m}^{-2}$ day $^{-1}$, which is approximately equal to the average total solar irradiance (no clouds) on a vertical surface, or ca. $30 \%$ of that on a horizontal surface in the temperate zone. Since the majority of these succulents intercept PAR in this range during the summer, there is essentially no light saturation of nocturnal acidification and of $\mathrm{CO}_{2}$ uptake capacity in these CAM plants under field conditions.

Several studies indicate that rates of nocturnal $\mathrm{CO}_{2}$ uptake in the CAM epiphyte Spanish moss (Tillandsia usneoides L.) saturate at irradiances lower than that received by a vertical surface on a cloudless day. According to KLUGE et al. (1973), total nighttime $\mathrm{CO}_{2}$ uptake increased slightly from $10 \mathrm{~mol} \mathrm{~m}^{-2}$ day $^{-1}$ to $20 \mathrm{~mol} \mathrm{~m}^{-2}$ day $^{-1}$ and did not change at $40 \mathrm{~mol} \mathrm{~m}^{-2}$ day $^{-1}$ (daytime PAR levels estimated from lux data presented). Likewise, MARTIN and SIEDOW (1981) found that nighttime $\mathrm{CO}_{2}$ uptake rates in Spanish moss were saturated at ca. $16 \mathrm{~mol} \mathrm{~m}^{-2}$ day $^{-1}$. BENZING and RENFROW (1971), using detached, slit leaves of Spanish moss, found photosynthetic saturation at $24 \mathrm{klx}$, or ca. $13 \mathrm{~mol} \mathrm{~m}^{-2}$ day $^{-1}$. It should be emphasized that these irradiance levels were presumably those intercepted by the plants and are substantially below full sunlight. Since Spanish moss and other epiphytes grow in a wide variety of microsites, including full sunlight such as outer tree canopies and on power lines as well as in deep shade such as the interior of tree canopies, this low-light saturation of nocturnal $\mathrm{CO}_{2}$ uptake may not be unexpected. Photosynthesis could be maximized throughout a range of irradiance levels by one or 
both of two mechanisms: (1) Spanish moss shares physiological characteristics with typical sun or shade plants, yet can grow at all levels of PAR by making morphological adjustments (perhaps by altering the density of its reflective trichomes; BENZING and RENFROW [1971]); or (2) the species exhibits a high flexibility in the physiological traits important in light absorption and use.

Given the paucity of information on adaptations of CAM plants, especially epiphytes, to different irradiance levels, the objectives of this study are to characterize the morphology, pigments, and nocturnal acid accumulations of Spanish moss grown under different light regimes in situ and in the greenhouse.

\section{Material and methods}

\section{FIELD STUDIES}

The study area was located near the Steel Creek delta, Savannah River Plant, South Carolina. Spanish moss was collected from Quercus laurifolia Michx. trees at three sites: (1) HI-alongside an unpaved road running east and west; (2) MIca. $2 \mathrm{~m}$ into the forest (often the canopy of the same tree, but the portion farthest from the road); and (3) LI-ca. $5 \mathrm{~m}$ into the forest. PAR was measured with a LI-COR LI-190SB sensor and LI-185B meter at 1100 hours (no clouds) on July 2, 1983. The sensor was held at the outer edge of each clump of Spanish moss and pointed directly at the sun and at the same angle in each of the four cardinal directions.

The living, distal portion of four to five strands of Spanish moss constituted one sample for acidity determinations; Chl measurements were made on single strands. Each site provided 20-25 samples for the acidity and $\mathrm{Chl}$ analyses. To determine diurnal acid fluctuations, samples were collected at dusk (2000 hours) on June 27, 1983, after a mostly clear day, and at dawn (0600 hours) the following morning. Samples were immediately frozen on dry ice and stored in the laboratory at $-25 \mathrm{C}$ until analyzed. Plants for $\mathrm{Chl}$ determinations were collected on June 27, 1983, frozen at -25 C, and analyzed. At each site, 25 strands were detached and placed in FAA $(5: 1: 25: 20)$.

\section{GREENHOUSE STUDIES}

Clumps of Spanish moss were collected in October $1983 \mathrm{ca}$. $20 \mathrm{~km}$ south of Melbourne Beach, Florida, and returned to the University of Kansas greenhouse. After 1 mo under greenhouse conditions (ca. $500 \mu \mathrm{mol} \mathrm{m}^{-2} \mathrm{~s}^{-1}$ PAR, 16-h photoperiod including artificial lighting; ca. 30/20 C day/ night and $40 \% / 80 \%$ day/night relative humidity), the clumps were separated into two groups. One group was hung vertically in a plastic window screen enclosure and received maximum irradiance of 100 $200 \mu \mathrm{mol} \mathrm{m} \mathrm{m}^{-2} \mathrm{~s}^{-1}$ PAR at midday (GLI), whereas the other group was hung in full sunlight $(1,500$ $1,600 \mu \mathrm{mol} \mathrm{m} \mathrm{m}^{-2} \mathrm{~s}^{-1}$ PAR; GHI). Irradiance levels, measured with the sensor parallel to the long axis of the plants, were not constant throughout the study because of frequent cloud cover and shading from nearby campus buildings. Before being exposed to these light levels, numerous strands were marked with black ink at the base of the youngest leaves so that new growth could be identified for morphological measurements.

Collections for morphological, pigment, and acidity analyses were made after 2 mo at GLI and GHI. Only new growth was placed in FAA and used for morphological measurements. Samples for pigment and acidity analyses included old and new growth. To determine diurnal acid fluctuations, 10 strands from each group were collected at dawn (0630 hours) and dusk (1730 hours) on January 26, 1984. Previously sampled strands were not used. Plants were immediately frozen on dry ice and stored at $-70 \mathrm{C}$ in the laboratory. Ten strands from each light level were collected on January 19, 1984, and analyzed for Chl content.

\section{MORPHOLOGICAL MEASUREMENTS}

Leaf and internode lengths were measured. Leaf width and thickness; trichome density, length, and width; and stomatal density, length, and width were determined with a light microscope and an ocular micrometer scale. Trichomes were removed from preserved material with adhesive tape to facilitate measuring trichome dimensions and to visualize the stomata, which are normally obscured by the trichome wings. All trichome and stomatal measurements were made at the center of each leaf. Stomatal length was measured parallel with the closed pore.

\section{PIgMENT ANALyses}

Material was kept on ice in dim light. After dead parts were removed, plants were ground with a mortar and pestle in $80 \%$ aqueous acetone containing $\mathrm{MgCO}_{3}$ to prevent pheophytinization. Field samples were vacuum-filtered; greenhouse samples were centrifuged at $12,000 \mathrm{~g}$ for $3 \mathrm{~min}$. In both cases, the residue was recovered, dried at $60 \mathrm{C}$ for 2 days (field) or $85 \mathrm{C}$ for at least 3 days (greenhouse), cooled in a desiccator, and weighed. The DWs of field samples were corrected for weight loss from the filter paper. The acetone extract was analyzed spectrophotometrically at 645,663 , and $720 \mathrm{~nm}$. Absorbance at $720 \mathrm{~nm}$ was subtracted from the other two values to minimize the influence of impurities (ŠESTÁK 1971). Concentrations of Chl a and b were calculated (ARNON 1949). 


\section{TITRATABLE ACIDITY ANALYSES}

After dead material was removed, samples were homogenized to determine titratable acidity (MARTIN et al. 1981). The DWs of the field samples were determined as above. Greenhouse samples were evaporated to dryness after titration and dried at $85 \mathrm{C}$ for at least 3 days before desiccation and weighing.

\section{STATISTICS}

Mean values from the three field locations were compared by one-way analyses of variance and the two greenhouse groups by $t$-tests. Both tests were performed by the Minitab computer software package (RYAN et al. 1981).

\section{Results}

\section{FIELD STUDIES}

Although differences in irradiance between the LI and MI sites were small at the time of measurement, it is clear that the HI site received greater amounts of PAR than did the other locations (table 1). There were no significant differences in leaf length, internode length, and leaf thickness among strands of Spanish moss collected from the three sites (table 2). A highly significant difference was found in leaf width among the three groups of plants, but the actual differences were small and did not vary consistently; i.e., they did not correlate with the light gradient (table 2).

Trichome density was higher at the LI and MI sites than at the HI site (table 3). Also, trichomes were smallest in the most dimly lit location. Stomata showed a similar trend: the plants at the LI site had the highest density (table 4), and the stomata were slightly wider but not as long as those on the HI plants.

Chl concentrations in strands of Spanish moss
TABLE 1

PAR LEVELS INCIDENT ON SPANISH MOSS

\begin{tabular}{|c|c|c|c|}
\hline \multirow[b]{2}{*}{ EXPOSURE } & \multicolumn{3}{|c|}{$\operatorname{PAR}\left(\mu \mathrm{mol} \mathrm{m}{ }^{-2} \mathrm{~s}^{-1}\right)$} \\
\hline & $\mathrm{HI}$ & MI & LI \\
\hline Direct solar & $1,008 \pm 313$ & $82 \pm 24$ & $55 \pm 37 * * *$ \\
\hline North $\ldots$. & $416 \pm 215$ & $198 \pm 227$ & $40 \pm 15^{*}$ \\
\hline South & $301 \pm 216$ & $30 \pm 13$ & $21 \pm 7 * *$ \\
\hline East $\ldots \ldots$. & $860 \pm 368$ & $100 \pm 113$ & $44 \pm 12^{* * *}$ \\
\hline West ... & $72 \pm 32$ & $25 \pm 8$ & $17 \pm 11^{* *}$ \\
\hline
\end{tabular}

NoTE. $-\mathrm{HI}=$ roadside near Steel Creek, S.C.; MI $=2 \mathrm{~m}$ into the forest; $L I=5 \mathrm{~m}$ into the forest. Probabilities are the results of one-way analyses of variance. No. $=5$.

$* P<.05$.

$* * P<.01$

$* * * P<.001$.

decreased as the irradiance level of the site increased (table 5). On the other hand, there were no differences in $\mathrm{Chl} \mathrm{a/b}$ ratios among the three groups. Although the LI plants contained significantly more acid at the end of a day than did the other plants, there were no differences by morning (table 6). Since acid levels were always highest in the LI plants, the nocturnal acid accumulation (A.M.-P.M.) was approximately equal in all three groups (table 6). Use of statistics in this case was not possible since the same strands were not sampled at each time of day; thus, only the mean acidities could be subtracted.

\section{GREENHOUSE STUDIES}

After 2 mo of exposure in the greenhouse, more biomass had been produced by the GHI than the GLI plants. The total DW biomass of 20 newly developed leaves was $0.0095 \mathrm{~g}$ (GHI) and 0.0021 $\mathrm{g}$ (GLI). These differences are reflected in the significantly greater leaf lengths in the GHI plants (table

TABLE 2

LEAF AND INTERNODE DIMENSIONS IN SPANISH MOSS

\begin{tabular}{|c|c|c|c|c|c|c|c|}
\hline \multirow[b]{2}{*}{ Dimensions } & \multicolumn{7}{|c|}{ IRRADIANCE } \\
\hline & & $\mathrm{HI}$ & & MI & LI & GHI & GLI \\
\hline $\begin{array}{l}\text { Internode length }(\mathrm{mm}) \ldots \ldots \ldots \\
\quad \text { No. internodes } \ldots \ldots \ldots\end{array}$ & 33.4 & $\begin{array}{l} \pm 15.4 \\
68\end{array}$ & 31.3 & $\begin{array}{l} \pm 15.8 \\
74\end{array}$ & $29.0 \pm 14.7^{\mathrm{a}}$ & $\ldots$ & $\begin{array}{l}\cdots \\
\ldots\end{array}$ \\
\hline $\begin{array}{l}\text { Leaf length }(\mathrm{mm}) \ldots \ldots \ldots \ldots \ldots \\
\quad \text { No. leaves } \ldots \ldots \ldots \ldots \ldots\end{array}$ & 41.7 & \pm 8.4 & 45.2 & \pm 11.6 & $43.0 \pm 18.4^{\mathrm{a}}$ & $18.1 \pm 5.0$ & $\begin{array}{c}6.4 \pm 2.3 * * * \\
20\end{array}$ \\
\hline $\begin{array}{l}\text { Leaf width }(\mathrm{mm}) \ldots \ldots \ldots \ldots \\
\quad \text { No. leaves } \ldots \ldots \ldots \ldots \ldots\end{array}$ & & $+\frac{ \pm}{77} .06$ & & $\pm \frac{ \pm}{75}$ & $.43 \pm \pm_{75} .04 * * *$ & $.71 \pm .11$ & $.67 \pm \frac{ \pm .12^{\mathrm{a}}}{20}$ \\
\hline $\begin{array}{l}\text { Leaf thickness }(\mathrm{mm}) \ldots \ldots \ldots \\
\quad \text { No. leaves } \ldots \ldots \ldots \ldots \ldots\end{array}$ & & $\frac{3 \pm}{124}$ & .27 & $\frac{ \pm}{75} \quad .05$ & $.27 \pm_{75} .03^{a}$ & $\begin{array}{r}.49 \pm \\
20\end{array}$ & $.48 \pm \frac{1}{20} .12^{\mathrm{a}}$ \\
\hline
\end{tabular}

NoTE.-HI = roadside near Steel Creek, S.C.; $\mathrm{MI}=2 \mathrm{~m}$ into the forest; $\mathrm{LI}=5 \mathrm{~m}$ into the forest; GHI $=$ exposed $2 \mathrm{mo}$ to high irradiance in the greenhouse; GLI = exposed 2 mo to low irradiance in the greenhouse. Values are means \pm SD. Probabilities are the results of one-way analyses of variance (HI, MI, LI) and of $t$-tests (GHI, GLI).

${ }^{a}$ No significant difference $(P>.05)$.

$* * * P<.001$. 
TABLE 3

TRICHOME DENSITIES AND DIMENSIONS IN SPANISH MOSS

\begin{tabular}{|c|c|c|c|c|c|}
\hline \multirow[b]{2}{*}{ DENSITY, DIMENSIONS } & \multicolumn{5}{|c|}{ IRRADIANCE } \\
\hline & $\mathrm{HI}$ & MI & LI & GHI & GLI \\
\hline $\begin{array}{l}\text { Trichome density }\left(\mathrm{mm}^{-2}\right) \ldots \ldots \\
\text { No. leaves } \ldots \ldots \ldots \ldots \ldots \\
\text { Trichome length }(\mu \mathrm{m}) \ldots \ldots \ldots \\
\text { No. trichomes } \ldots \ldots \ldots \ldots \\
\text { Trichome width }(\mu \mathrm{m}) \ldots \ldots \ldots \\
\text { No. trichomes } \ldots \ldots \ldots \ldots\end{array}$ & $\begin{array}{l}32.1 \pm 5.6 \\
77 \\
609 \pm 79 \\
234 \\
269 \pm 42 \\
234\end{array}$ & $\begin{array}{l}34.8 \pm 5.4 \\
75 \\
609 \pm 92 \\
225 \\
264 \pm 39 \\
225\end{array}$ & $\begin{array}{c}34.9 \pm 6.3^{* * * *} \\
75 \\
565 \pm 87^{* * *} \\
222 \\
258 \pm 33^{* *} \\
222\end{array}$ & $\begin{array}{c}45.5 \pm 11.2 \\
20 \\
593 \pm 141 \\
100 \\
287 \pm 55 \\
100\end{array}$ & $\begin{array}{c}47.4 \pm 8.1^{\mathrm{a}} \\
20 \\
600 \pm 127^{\mathrm{a}} \\
100 \\
250 \pm 41^{* * *} \\
100\end{array}$ \\
\hline
\end{tabular}

NoTE.-HI = roadside near Steel Creek, S.C.; MI $=2 \mathrm{~m}$ into the forest; $\mathrm{LI}=5 \mathrm{~m}$ into the forest; GHI $=$ exposed 2 mo to high irradiance in the greenhouse; GLI $=$ exposed 2 mo to low irradiance in the greenhouse. Values are means \pm SD. Probabilities are the results of one-way analyses of variance (HI, MI, LI) and of $t$-tests (GHI, GLI). Trichomes were measured on 75 leaves from 25 strands (HI, MI, LI) and on 20 leaves from 20 strands (GHI, GLI).

No significant difference $(P>.05)$.

** $P<.01$.

$* * * P<.001$

2). All of the morphological data were taken only from leaves that had developed under the appropriate light treatment. No differences in leaf width or thickness were found (table 2).

Trichome density and length did not vary for plants grown at the two light levels; however, trichomes were wider on the leaves of plants exposed to GHI (table 3). There were no significant differences in stomatal density, length, and width among leaves grown under GHI and GLI (table 4).

$\mathrm{Chl}$ concentrations were significantly higher in leaves of the GLI plants than in those of GHI plants; yet the $\mathrm{Chl} \mathrm{a/b}$ ratios did not vary (table 5). Plants grown under GHI exhibited greater acid fluctuations than those grown under GLI (table 6).

\section{Discussion}

In spite of the differences in collection sites (South Carolina and Florida) and environmental condi- tions during growth (summer field conditions and winter greenhouse conditions), most responses of the two groups of Spanish moss to differing levels of irradiance were similar. The field study indicated that, unlike most species (DENGLER 1980; BJÖRKMAN 1981), leaf morphological characteristics varied only slightly among plants grown at the three irradiance levels. This was also true for plants grown in the greenhouse, except that the GHI leaves were longer than the GLI leaves. This reflects the lower energy input, hence carbon gain, available to the GLI plants. The acid accumulation data support this contention.

BENZING and RENFROW (1971) reported trichome densities of $44-45 \mathrm{~mm}^{-2}$ for Spanish moss from Mexico or Central America. By comparison, trichomes on leaves of the South Carolina plants were less dense and those of the Florida plants were slightly more dense. Given the small differences

TABLE 4

StOMATAL DENSITIES AND DIMENSIONS IN SPANISH MOSS

\begin{tabular}{|c|c|c|c|c|c|}
\hline \multirow[b]{2}{*}{ DENSITY, DIMENSIONS } & \multicolumn{5}{|c|}{ IRRADIANCE } \\
\hline & HI & MI & LI & GHI & GLI \\
\hline $\begin{array}{l}\text { Stomatal density }\left(\mathrm{mm}^{-2}\right) \ldots \ldots \ldots \ldots \\
\quad \text { No. leaves } \ldots \ldots \ldots \ldots \ldots \ldots \\
\text { Stomatal length }(\mu \mathrm{m}) \ldots \ldots \ldots \ldots \ldots \\
\text { No. stomata } \ldots \ldots \ldots \ldots \ldots \ldots \\
\text { Stomatal width }(\mu \mathrm{m}) \ldots \ldots \ldots \ldots \ldots \\
\quad \text { No. stomata. } \ldots \ldots \ldots \ldots \ldots \ldots\end{array}$ & $\begin{array}{l}11.7 \pm 4.6 \\
76 \\
29.5 \pm 3.4 \\
235 \\
29.4 \pm 3.2 \\
235\end{array}$ & $\begin{array}{l}13.1 \pm 4.2 \\
75 \\
29.5 \pm 3.3 \\
225 \\
28.5 \pm 2.3 \\
225\end{array}$ & $\begin{array}{l}14.7 \pm 4.1^{* * *} \\
75 \\
30.2 \pm 3.1^{*} \\
222 \\
28.3 \pm 2.6^{* * *} \\
222\end{array}$ & $\begin{array}{c}25.9 \pm 7.6 \\
20 \\
28.8 \pm 4.2 \\
98 \\
32.3 \pm 4.2 \\
98\end{array}$ & $\begin{array}{l}25.6 \pm 10.4^{\mathrm{a}} \\
19 \\
28.4 \pm \frac{ \pm}{84} 4.3^{\mathrm{a}} \\
31.9 \stackrel{ \pm}{84} 3.8^{\mathrm{a}}\end{array}$ \\
\hline
\end{tabular}

NoTE. - HI = roadside near Steel Creek, S.C.; $\mathrm{MI}=2 \mathrm{~m}$ into the forest; $\mathrm{LI}=5 \mathrm{~m}$ into the forest; GHI $=$ exposed $2 \mathrm{mo}$ to high irradiance in the greenhouse; GLI = exposed 2 mo to low irradiance in the greenhouse. Values are means \pm SD. Probabilities are the results of one-way analyses of variance (HI, MI, LI; 75 leaves from 25 strands) and of $t$ tests (GHI, GLI; 20 leaves from 20 strands).

No significant difference $(P>.05)$.

$* P<.05$.

$* * * P<.001$ 
TABLE 5

CHL CONCENTRATIONS AND a/b RATIOS IN SPANISH MOSS

\begin{tabular}{ccc}
\hline \multicolumn{4}{c}{$\begin{array}{c}\mathrm{Chl} \\
\text { Exposure }\end{array}$} & $\left(\mathrm{mg} \mathrm{g}^{-1} \mathrm{DW}\right)$ & $\mathrm{Chl} \mathrm{a} / \mathrm{b}$ \\
\hline HI $\ldots \ldots \ldots$ & $1.75 \pm .61$ & $2.75 \pm .20$ \\
MI $\ldots \ldots \ldots$ & $3.09 \pm 1.51$ & $2.85 \pm .22$ \\
LI $\ldots \ldots \ldots$ & $4.08 \pm 2.51^{* * *}$ & $2.81 \pm .16^{\mathrm{a}}$ \\
GHI $\ldots \ldots \ldots$ & $1.51 \pm .34$ & $2.67 \pm .31$ \\
GLI $\ldots \ldots \ldots$ & $2.08 \pm .41^{* *}$ & $2.56 \pm .15^{\mathrm{a}}$
\end{tabular}

NoTE.-HI = roadside near Steel Creek, S.C.; MI $=2 \mathrm{~m}$ into the forest; $\mathrm{LI}=5 \mathrm{~m}$ into the forest; $\mathrm{GHI}$ $=$ exposed 2 mo to high irradiance in the greenhouse; GLI $=$ exposed 2 mo to low irradiance in the greenhouse. Values are means \pm SD. Probabilities are the results of one-way analyses of variance (HI, MI, LI; no. $=25)$ and of $t$-tests (GHI, GLI; no. $=10)$.

a No significant difference $(P>.05)$.

$* * P<.01$.

$* * * P<.001$

among the plants in our study, it seems reasonable to assume that the shielding and reflective qualities imparted by the denser indumentum are offset by the smaller trichomes in the LI plants.

Stomatal densities in this study exceeded that $(7$ $\mathrm{mm}^{-2}$ ) reported by BILLINGS (1904) for Spanish moss in Louisiana. The minor differences in stomatal sizes and densities among plants in our study are presumably biologically insignificant.

Chl concentrations of Spanish moss from South Carolina and Florida were typically higher than those (0.8-1.6 $\left.\mathrm{mg} \mathrm{Chl} \mathrm{g}^{-1} \mathrm{DW}\right)$ of MARTIN and SIEDOW (1981) in North Carolina. Changes in pigment concentrations in response to irradiance were identical in the field and greenhouse studies. The absence of a response to irradiance for the $\mathrm{Chl} \mathrm{a/b}$ ratios in Spanish moss was unexpected, given the large differences in Chl concentrations. However, similar results have been found with other species
(MARTIN and CHURCHILl 1982; VAPAAVUORI and NURMI 1982). Apparently, both $\mathrm{Chl}$ a and b can respond simultaneously to changing irradiance.

Our tissue titratable acidity data parallel those of MARTIN et al. (1981) in North Carolina. Acidification in field plants generally exceeded that of greenhouse plants. This disparity may be related to differences in integrated diurnal irradiance levels, temperature, humidity, and frequency of water stress during growth in the field and in the greenhouse. The acid fluctuation data indicate that the GLI plants were exposed to light levels below the saturation point of nocturnal acid accumulation. Apparently light levels at each of the three field sites were saturating with respect to nocturnal carbon gains. Either the South Carolina plants light saturated at a lower irradiance than did the greenhouse-grown Florida plants or the daily integrated irradiances in the field and in the greenhouse were not represented by the one-time measurements reported above. Evidence to support the second explanation includes: (1) The greenhouse plants were often shaded by nearby buildings and were certainly not receiving the maximum PAR levels indicated above throughout each day of the experiment; and (2) the LI plants in the field probably received more light than indicated above as a result of exposure to sun flecks. These hypotheses are not supported by the pigment data, however, since light saturation was not observed. Perhaps changes in pigment concentration and nocturnal acid accumulation do not saturate at the same light level. Unfortunately, no data on this subject could be located.

This study indicates that Spanish moss does not respond to different levels of irradiance by altering its morphology. On the other hand, nocturnal acid accumulation appeared to saturate at low irradiances and $\mathrm{Chl}$ concentrations changed with changing irradiance level. Considering (1) the slow growth rate of this CAM epiphyte (MARTIN et al. 1981),

TABLE 6

TISSUE TITRATABle ACIDITY IN SPANISH MOSS

\begin{tabular}{|c|c|c|c|}
\hline Exposure & $\begin{array}{c}\text { Dawn titratable } \\
\left.\text { acidity ( } \mu \text { eq } \mathrm{g}^{-1} \mathrm{DW}\right)\end{array}$ & $\begin{array}{c}\text { Dusk titratable } \\
\left.\text { acidity ( } \mu \text { eq } \mathrm{g}^{-1} \mathrm{DW}\right)\end{array}$ & $\begin{array}{c}\text { Difference } \\
\left(\mu \text { eq } \mathrm{g}^{-1} \mathrm{DW}\right)\end{array}$ \\
\hline $\mathrm{HI}$ & $611 \pm 48$ & $111.9 \pm 28.4$ & 499.1 \\
\hline MI $\ldots . .$. & $618 \pm 111$ & $154.6 \pm 42.7$ & 463.4 \\
\hline LI $\ldots \ldots$ & $666 \pm 188^{\mathrm{a}}$ & $193.6 \pm 68.9^{* * *}$ & 472.4 \\
\hline GHI $\ldots$ & $381 \pm 55$ & $77.7 \pm 14.5$ & 303.8 \\
\hline GLI $\ldots \ldots \ldots$ & $266 \pm 38^{* * *}$ & $90.9 \pm 31.1^{\mathrm{a}}$ & 175.1 \\
\hline
\end{tabular}

NoTE.-HI $=$ roadside near Steel Creek, S.C.; $\mathrm{MI}=2 \mathrm{~m}$ into the forest; $\mathrm{LI}=5 \mathrm{~m}$ into the forest; GHI = exposed 2 mo to high irradiance in the greenhouse; GLI $=$ exposed 2 mo to low irradiance in the greenhouse. Values are means \pm SD. Probabilities are the results of one-way analyses of variance (HI, MI, LI; no. $=20$ ) and of $t$-tests (GHI, GLI; no. $=10)$.

${ }^{a}$ No significant difference $(P>.05)$

$* * * P<.001$. 
(2) its propensity for vegetative reproduction in the form of windblown strands (GARTH 1964) potentially resulting in rapid and drastic changes in irradiance exposure, and (3) seasonal changes in irradiance related to the solar trajectory as well as host deciduousness, physiological responses enhancing the utilization of ambient light by Spanish moss should be much more rapidly initiated than would be morphological changes in new tissue. These observations may explain the ability of Spanish moss to inhabit tree canopy microsites of widely varying irradiance levels.

\section{Acknowledgments}

The financial and logistical support of the $\mathrm{Sa}$ vannah River Ecology Laboratory and United States Department of Energy grant EY-76-C-09-0819 with the Institute of Ecology, University of Georgia, is appreciated. L. Donovan, K. ShERrod, and M. TOPA provided excellent help in the laboratory. C. FISHER and V. NEw graciously provided the Florida plants. M. SMrTH and R. PITNER improved the style of the manuscript, which was prepared with the able assistance of J. ELDER and C. SPENCER.

\section{LITERATURE CITED}

ARNON, D. I. 1949. Copper enzymes in isolated chloroplasts. Polyphenoloxidase in Beta vulgaris. Plant Physiol. 24:1-15.

BENZING, D. H., and A. RENFrow. 1971. The significance of photosynthetic efficiency to habitat preference and phylogeny among tillandsioid bromeliads. BoT. GAZ. 132:19-30.

BILLINGS, F. H. 1904. A study of Tillandsia usneoides. Bot. GAZ. 38:99-121.

BJÖRKMAN, O. 1981. Responses to different quantum flux densities. Pages 57-107 in O. L. LANGe, P. S. Nobel, C. B. OSMOND, and H. ZIEGLER, eds. Physiological plant ecology. Vol. 1. Responses to the physical environment. Springer, Berlin.

BOARDMAN, N. K. 1977. Comparative photosynthesis of sun and shade plants. Annu. Rev. Plant Physiol. 28:355-377.

DENGLER, N. G. 1980. Comparative histological basis of sun and shade leaf dimorphism in Helianthus annuus. Can. J. Bot. 58:717-730.

GARTH, R. E. 1964. The ecology of spanish moss (Tillandsia usneoides): its growth and distribution. Ecology 45:470-481.

Kaplan, A., J. Gale, and A. Poljakoff-Mayber. 1976a. Simultaneous measurement of oxygen, carbon dioxide, and water vapour exchange of intact plants. J. Exp. Bot. 97:214219.

21976b. Resolution of net dark fixation of carbon dioxide into its respiration and gross fixation components in Bryophyllum daigremontianum. J. Exp. Bot. 97:220-230.

KLUGE, M., O. L. LANGe, M. V. EICHManN, and R. SCHMid. 1973. Diurnaler Säurerhythmus bei Tillandsia usneoides: Untersuchungen über den Weg des Kohlenstoffs sowie die Abhängigkeit des $\mathrm{CO}_{2}$-Gaswechsels von Lichtintensität, Temperatur und Wassergehalt der Pflanze. Planta 112:357372.

Martin, C. E., N. L. Christensen, and B. R. Strain. 1981. Seasonal patterns of growth, tissue acid fluctuations, and ${ }^{14} \mathrm{CO}_{2}$ uptake in the Crassulacean acid metabolism epiphyte Tillandsia usneoides L. (Spanish moss). Oecologia 49:322-328.

MARTIN, C. E., and S. P. ChURCHILl. 1982. Chlorophyll concentrations and $\mathrm{a} / \mathrm{b}$ ratios in mosses collected from exposed and shaded habitats in Kansas. J. Bryol. 12:297-304.

MARTIN, C. E., and J. N. SiEDOw. 1981. Crassulacean acid metabolism in the epiphyte Tillandsia usneoides L. (Spanish moss). Responses of $\mathrm{CO}_{2}$ exchange to controlled environmental conditions. Plant Physiol. 68:335-339.

NoBel, P. 1982a. Interaction between morphology, PAR interception, and nocturnal acid accumulation in cacti. Pages 260-277 in I. P. TING and M. GIBBS, eds. Crassulacean acid metabolism. Am. Soc. Plant Physiol., Rockville, Md.

NoBel, P. S. $1982 b$. Orientation, PAR interception, and nocturnal acidity increases for terminal cladodes of a widely cul- tivated cactus, Opuntia ficus-indica. Am. J. Bot. 69:14621469.

- 1983. Spine influences on PAR interception, stem temperature, and nocturnal acid accumulation by cacti. Plant Cell Environ. 6: 153-159.

NoBel, P. S., and T. L. HARTSOCK. 1978. Resistance analysis of nocturnal carbon dioxide uptake by a Crassulacean acid metabolism succulent, Agave deserti. Plant Physiol. 61:510514.

1983. Relationships between photosynthetically active radiation, nocturnal acid accumulation, and $\mathrm{CO}_{2}$ uptake for a Crassulacean acid metabolism plant, Opuntia ficus-indica. Plant Physiol. 71:71-75.

Nose, A., M. Shiroma, K. Mryazato, and S. Murayama. 1977. Studies on matter production in pineapple plants. I. Effects of light intensity in light period on the $\mathrm{CO}_{2}$ exchange and $\mathrm{CO}_{2}$ balance of pineapple plants. Jpn. J. Crop Sci. 46:580587.

RYAN, T. A., JR., B. L. JoINER, and B. F. RYAN. 1981. Minitab reference manual. Duxbury Press, Boston.

Sale, P. J. M., and T. F. NEales. 1980. Carbon dioxide assimilation by pineapple plants, Ananas comosus (L.) Merr. I. Effects of daily irradiance. Aust. J. Plant Physiol. 7:363373.

ŠESTÁK, Z. 1971. Determination of chlorophylls $a$ and $b$. Pages 672-701 in Z. ŠESTÁK, J. ČATSKÝ, and P. G. JARVIS, eds. Plant photosynthetic production. Manual of methods. Junk, The Hague.

TALBERT, C. M., and A. E. HolCH. 1957. A study of the lobing of sun and shade leaves. Ecology 38:655-658.

VAPAAVUORI, E., and A. NURMI. 1982. Chlorophyll-protein complexes in Salix sp. 'Aquatica Gigantea' under strong and weak light. II. Effect of water stress on the chlorophyll-protein complexes and chloroplast ultrastructure. Plant Cell Physiol. 23:791-801.

WILD, A., and G. Wolf. 1980. The effect of different light intensities on the frequency and size of stomata, the size of cells, the number, size and chlorophyll content of chloroplasts in the mesophyll and the guard cells during the ontogeny of primary leaves of Sinapis alba. Z. Pflanzenphysiol. 97:325-342.

WoOdHOUSE, R. M., J. G. Williams, and P. S. Nobel. 1980. Leaf orientation, radiation interception, and nocturnal acidity increases by the CAM plant Agave deserti (Agavaceae). Am. J. Bot. 67:1179-1185.

ZABKA, G. G., and J. Edelman. 1962. Pre-illumination as a factor in the dark fixation of carbon dioxide by leaf disks of Kalanchoe blossfeldiana var. Feuer Blute. J. Exp. Bot. 13:1219. 